ORIGINAL RESEARCH ARTICLE

\title{
Phyto-adsorption treatment of paper mill effluent using leaf powder of water hyacinth (Eichhornia crassipes [Mart.] Solms
}

\author{
Akshay Kumar, Roushan K. Thakur, Jogendra Singh, A.K. Chopra and Vinod Kumar* \\ Agro-ecology and Pollution Research Laboratory, Department of Zoology and Environmental Science, Gurukula Kangri University \\ Haridwar-249404 (Uttarakhand), India \\ "Correspondence author's E-mail: drvksorwal@gmail.com
}

\begin{tabular}{l} 
ARTICLE HISTORY \\
\hline Received: 20 September 2017 \\
Revised received: 28 October 2017 \\
Accepted: 26 November 2017 \\
Keywords \\
\hline
\end{tabular}

Paper mill effluent

Phyto-adsorbent

Removal efficiency

Treatment

Water hyacinth

\begin{abstract}
In this present study, an experiment was performed to find the potential of leaf powder of water hyacinth (Eichhornia crassipes) in treating paper mill effluent. During the study the value of different parameters viz., $\mathrm{pH}(5.80 \pm 0.10)$, TDS $\left(980.22 \pm 12.52 \mathrm{mgL}^{-1}\right)$, EC $\left(6.52 \pm 0.11 \mathrm{dS} \mathrm{m} \mathrm{m}^{-1}\right)$, BOD $\left(86.42 \pm 4.61 \mathrm{mgL}^{-1}\right), \mathrm{COD}\left(281.01 \pm 8.66 \mathrm{mgL}^{-1}\right), \mathrm{PO}_{4}{ }^{3-}\left(71.46 \pm 6.00 \mathrm{mgL}^{-1}\right), \mathrm{TKN}\left(84.99 \pm 3.92 \mathrm{mgL}^{-1}\right)$, $\mathrm{Na}\left(136.94 \pm 6.66 \mathrm{mgL}^{-1}\right), \mathrm{K}\left(95.01 \pm 3.48 \mathrm{mgL}^{-1}\right)$ and total hardness $\left(442.39 \pm 3.78 \mathrm{mgL}^{-1}\right)$ of paper mill effluent were recorded higher before bio-adsorption treatment using leaf powder of $E$. crassipes. The leaf powder of $E$. crassipes significantly $(\mathrm{P}<0.05 / \mathrm{P}<0.01)$ removed TDS, EC, BOD, COD, TKN, Na, $\mathrm{K}$ and total hardness of the paper mill effluent. The result of the present study on the bio-adsorption treatment using leaf powder of E. crassipes of paper mill effluent showed maximum reduction in the effluent characteristics viz., pH (6.62 \pm 0.08$)$, TDS $\left(848.42 \pm 7.67 \mathrm{mgL}^{-1}\right), \mathrm{EC}\left(4.08 \pm 0.17 \mathrm{dS} \mathrm{m}^{-1}\right)$, BOD $\left(62.56 \pm 3.39 \mathrm{mgL}^{-1}\right), \mathrm{COD}\left(218.11 \pm 8.59 \mathrm{mgL}^{-1}\right), \mathrm{PO}_{4}{ }^{3-}\left(50.13 \pm 4.33 \mathrm{mgL}^{-1}\right), \mathrm{TKN}\left(63.04 \pm 6.47 \mathrm{mgL}^{-1}\right)$, $\mathrm{Na}\left(100.06 \pm 6.99 \mathrm{mgL}^{-1}\right), \mathrm{K}\left(66.00 \pm 7.38 \mathrm{mgL}^{-1}\right)$ and total hardness $\left(347 \pm 9.86 \mathrm{mgL}^{-1}\right)$ of paper mill effluent after bio-adsorption treatment using leaf powder of $E$. crassipes. The maximum removal of TDS (13.45\%), EC (37.43\%), BOD (25.89\%), COD (22.38\%), $\mathrm{PO}_{4}{ }^{3-}(29.85 \%)$, TKN $(25.83 \%)$, Na $(26.94 \%), \mathrm{K}(30.54 \%)$ and total hardness $(21.56 \%)$ in the paper mill effluent were recovered after phyto-adsorption treatment using leaf powder of E. crassipes. The decrease of paper mill effluent parameter is likely due to that the leaf powder of water hyacinth absorbs the nutrient from the effluent. Therefore, the leaf powder of can be used as phyto-adsorbent for the removal of various pollution parameters.
\end{abstract}

(C)2017 Agriculture and Environmental Science Academy

Citation of this article: Kumar, A., Thakur, R.K., Singh, J., Chopra, A.K. and Kumar, V. (2017). Phyto-adsorption treatment of paper mill effluent using leaf powder of water hyacinth (Eichhornia crassipes [Mart.] Solms. Archives of Agriculture and Environmental Science, 2(4): 348-352, DOI: 10.26832/24566632.2017.020418

\section{INTRODUCTION}

In the recent times, the industrial pollution has emerged as a major threat to water resources around the world, particularly in the Global South (developing countries) where a scenario prevails that the pollution is a price to pay for progress (Greenpeace, 2011). This view is generally associated with numerous thoughts that the dealing with pollution is too costly, pollution prevention is too difficult and impractical; and that environmental and social impacts can be dealt with in the future. In contrast, the case studies from the Global North (developed countries) have exposed the extent to which persistent and bio-accumulative substances that had contaminated the regions till date, show the immense difficulties and a very high expense of restoration programmes and the impossibility of total decontamination (Greenpeace, 2011).

The paper industries are the sixth biggest noxious waste producing industries of the world. Paper manufacturing is an agro-based industry. The fast growth in population and the higher demand for industrial establishment to meet human necessity have produced evils such as overexploitation of obtainable resources and pollution of the land, air and water (Kumar et al., 2017a, b). The effluent generated is characterised by dark colour, foul odor and high organic content and extreme quantities of chemical oxygen demand (COD), biochemical oxygen demand (BOD) and $\mathrm{pH}$ (Pokhrel et al., 2004). The dark colour in paper mill effluent is caused due to the presence of organic ligands such as wood extractives, resins, products (Deilek et al., 2001).

Industrialization has become an important factor to the development of a country's economy, through the establishment of plants and factories However, the waste or by-products discharged from them are severely disastrous to the environment consists various kind of contaminant which contaminate the surface water, ground water and soil (Kumar et al., 2016; Kumar and Thakur, 2017). The application of microbial or plant biomass could be an effective, low cost and ecofriendly means for removal and/or recovery of toxic metals from contaminated wastewater and industrial effluents, even at low concentrations. Certain aquatic and terrestrial plants, composed of lignin, cellulose, hemi-cellulose, pectins, phytic 
acid and many proteins offer active sites such as carbonyl (CO), carboxyl $(-\mathrm{COO})$, hydroxyl $(-\mathrm{OH})$, amino $\left(-\mathrm{NH}_{2}\right)$ and sulfhydryl $(-\mathrm{SH})$ groups for binding of metal cations and make them popular for removing metals from contaminated waters (Shweta and Rai, 2010). Application of aquatic macrophytes in phytoremediation of industrial effluent has become popular due to the high cost and energy intense treatment technologies. Phytoremediation is the use of aquatic plants to remediate the organic and inorganic contaminants present in the industrial effluent. Aquatic macrophytes are accomplished to eliminate a broad range of nutrients as well as heavy metals from industrial effluent (Kumar et al., 2016; 2017c).

There is, however, a great need to undertake research to quantify the levels of damage and the costs of control, loss of livelihood, disease, and disruption of normal operations caused by water hyacinth (Nakanishi et al., 2002; Okafor et al., 2012; Pagnanelli et al., 2003; Rahman et al., 2005; Wirasnita et al., 2014; Tsai et al., 2006; Wan Ngah and Hanafiah, 2008; Wang et al., 2010). Many researchers have been reported the removal of different pollutants parameters from wastewater, industrial effluents and synthetic aqueous solutions using various plant based phyto-adsorbents (Annadurai et al., 2003; Ahmaruzzaman, 2008; Jain et al., 2010; Chang et al., 2012; Chairgulprasert et al., 2013; Lazim et al., 2015). Keeping in view the pollution due to the discharge of the paper mill effluent and ecological importance of water hyacinth (Eichhornia crassipes), the present research work was carried out to study the phyto-adsorption treatment of paper mill effluent using leaf powder of Eichhornia crassipes.

\section{MATERIALS AND METHODS}

Study sites: Star Paper Mill Ltd. Saharanpur, (Uttar Pradesh) was selected for the collection of paper mill effluent. The Star Paper Mill is located about $61.6 \mathrm{~km}$ away from Gurukula Kangri Vishwavidyalyaya (Haridwar) in the north east. The plants of water hyacinth (Eichhornia crassipes) were collected from the local pond situated at Jamalpur Kalan village $\left(29.9120^{\circ} \mathrm{N}\right.$ and $\left.78.1308^{\circ} \mathrm{E}\right)$ Haridwar (Uttarakhand), India. Fresh plants of water hyacinth were collected from local pond in Jamalpur village in Haridwar district. Leaves of the water hyacinth were plucked out and washed with double distilled water, and then it is left in sunlight until it is completely dried. Then with the help of mortar and pestle leaf samples were crushed into very fine particle. At last leaves of water hyacinth practical is sieved with a uniform particle sized 1.5 $\mathrm{mm}$ for experimental use and kept in air tight plastic bags.

Collection of paper mill effluent and analysis: The Star Paper mill effluent was collected from the untreated discharge channel outlet at Star Paper Mills Ltd. Saharanpur, (29 56'13.04"N 77³4'11.28"E) Uttar Pradesh. The samples were collected in thoroughly cleaned plastic container of 10 liters capacity provides with the double cap device. Some of the parameters like $\mathrm{pH}$ were carried out on the spot and dissolved oxygen (DO) was also fixed on the spot because time consumed during transportation could alter the results. Remaining parameters could be carried out on composite sample. The collected effluent samples of the paper mill effluent were brought to the laboratory. The effluent was analyzed before and after phyto-adsorption for different physico-chemical parameters viz., $\mathrm{pH}$, total dissolved solids (TDS), electrical conductivity (EC), biochemical oxygen demand (BOD), chemical oxygen demand (COD), phosphate $\left(\mathrm{PO}_{4}{ }^{3-}\right)$, total Kjeldhal nitrogen $(\mathrm{TKN})$, sodium $(\mathrm{Na})$ and potassium $(\mathrm{K})$ using water hyacinth (E. crassipes) at $6,12,24$, and 48 hours, respectively. The samples were analyzed for various physicchemical parameters by following standard techniques (APHA, 2012; Chaturvedi and Sarkar, 2006).

Experimental design: Four glass jars of 4 liters capacity were used for the phytoremediation study. A total 16 liters paper mill effluent were taken into four glass jar separately. Thus each glass jar contained 4 liters of paper mill effluent. $100 \mathrm{~g}$ air dried biomass of water hyacinth was transferred in the effluent and mixed as well as shacked it thoroughly. The experiments were conducted for $6,12,24$ and 48 hours of retention time.

Statistical analysis of data: The values reported in the present study were the mean of three replicates. The means were calculated with the help of MS Excel 2010 while the graphs were plotted with the help of Sigma plot, 2000.

\section{RESULTS AND DISCUSSION}

Characteristics of paper mill effluent: The mean $\pm \mathrm{SE}$ of various physico-chemicals characteristics paper mill effluent are given in Table 1. During the present study, the values of TDS (980.22 $\mathrm{mgL}^{-1}$ ) of paper mill effluent were recorded within the prescribed limit of Indian Standards for irrigation water (BIS, 2012). The higher values of TDS in the paper mill effluent were recorded as compared to the control (Bore well water) and this is likely due to the utilization of agro-residues in the manufacturing of paper by the paper mill (Table 1). Kumar and Chopra (2012) also recorded slightly lower values of TDS $\left(860 \pm 5.50 \mathrm{mgL}^{-1}\right)$ in the paper mill effluent. The $\mathrm{pH}$ of paper mill effluent was slightly acidic (5.80) in nature and it might be due to the use of acidic matters in the production of pulp from the raw material. The value of EC in the paper mill effluent was also noted to be higher and it is likely due to the presence of more ionic species in the paper mill effluent (Table 1). Higher values of EC $\left(6.84 \pm 0.40 \mathrm{dS} \mathrm{m}^{-1}\right)$ were also reported by Kumar and Chopra $(2012,2015)$ in the untreated paper mill effluent. The results showed that the values of BOD $\left(106.42 \mathrm{mgL}^{-1}\right)$, COD $\left(281.01 \mathrm{mgL}^{-1}\right)$ in the paper mill effluent were found beyond the irrigation standard (Table 1). The higher values of BOD and COD in the paper mill effluent are likely due to the presence of more degradable or oxidizable organic matter, inorganic chemical species or dissolved solids in the paper mill effluent as earlier reported by Kumar and Chopra (2012b). Ghaly et al. (2011) reported higher BOD $\left(1874.20 \mathrm{mgL}^{-1}\right)$ and COD $\left(2450.60 \mathrm{mgL}^{-1}\right)$ in the paper mill effluent.

During the present investigation, the values of $\mathrm{Na}+, \mathrm{K}+, \mathrm{TKN}$, $\mathrm{PO}_{4}{ }^{3-}$ and total hardness in the paper mill effluent were also found higher compared to the BIS standards (Table 1). The findings were in accordance with those of Patterson et al., (2008) who reported higher values of $\mathrm{Na}^{+}\left(70.90 \mathrm{mgL}^{-1}\right)$, and $\mathrm{PO}_{4}{ }^{3-}\left(64.98 \mathrm{mgL}^{-1}\right)$ in the paper mill effluent.

After phyto-adsorption treatment using leaf powder of water hyacinth the value of TDS $(951.33 \pm 9.56,888.49 \pm 8.53$, $855.96 \pm 7.50$ and $\left.848.42 .18 \pm 7.67 \mathrm{mgL}^{-1}\right)$, EC (5.95 \pm 0.11 , $4.92 \pm 0.15,4.11 \pm 0.18$ and $\left.4.08 \pm 0.17 \mathrm{dSm}^{-1}\right), \mathrm{pH}(6.07 \pm 0.01$, $6.24 \pm 0.14,6.61 \pm 0.12$ and $6.60 \pm 0.08)$, BOD $(84.49 \pm 5.64$, $77.93 \pm 4.92, \quad 63.77 \pm 4.40$ and $\left.62.56 \pm 3.39 \mathrm{mgL}^{-1}\right), \quad \mathrm{COD}$ $(274.57 \pm 9.85,248.54 \pm 4.29, \quad 220.29 \pm 9.03$ and $218.11 \pm 8.59$ $\left.\mathrm{mgL}^{-1}\right), \quad \mathrm{PO}_{4}{ }^{3-}(69.51 \pm 5.02, \quad 62.09 \pm 4.98, \quad 51.42 \pm 4.24$, and $\left.50.13 \pm 4.33 \quad \mathrm{mgL}^{-1}\right), \quad$ TKN $\quad(80.92 \pm 3.09, \quad 75.22 \pm 5.01$, $64.05 \pm 8.56$ and $\left.63.04 \pm 6.47 \mathrm{mgL}^{-1}\right), \quad \mathrm{Na}(133.31 \pm 3.60$, $127.50 \pm 4.87, \quad 101.91 \pm 13.16$ and $\left.100.06 \pm 6.99 \mathrm{mgL}^{-1}\right), \mathrm{K}$ $\left(89.90 \pm 2.34,80.56 \pm 3.56,66.76 \pm 7.29\right.$ and $\left.66.00 \pm 7.38 \mathrm{mgL}^{-1}\right)$ and total hardness $(421.89 \pm 3.02,395.74 \pm 4.54,362.56 \pm 9.15$ 
and $347 \pm 9.86 \mathrm{mgL}^{-1}$ ) were decreased after $6,12,24$ and 48 hours of phyto-adsorption treatment experiments, respectively (Table 1; Figure 1-5). Moreover, application of leaf powder of E. crassipes as phyto-adsorbent showed significant $(\mathrm{P}<0.05$ / $\mathrm{P}<0.01$ ) effect on the removal of TDS, EC, BOD, COD, TKN, $\mathrm{Na}, \mathrm{K}$ and hardness of the paper mill effluent at 12, 24 and 48 hours of phyto-adsorption treatment.

Additionally, the removal efficiency of the leaf powder of water hyacinth were recorded $(2.9 \%, 9.3 \%, 12.68 \%$ and $13.45 \%)$ for TDS, $(8.75 \%, 24.94 \%, 36.97 \%$ and $37.43 \%)$ for EC, $(2.24 \%, 9.83 \%$ a, $23.89 \%$ and $25.89 \%)$ for BOD, $(2.30 \%$, $11.56 \%, 21.61 \%$ and $22.38 \%)$ for COD, $(2.8 \%, 13.12 \%$,
$28.05 \%$ and $29.85 \%)$ for $\mathrm{PO}_{4}{ }^{3-},(4.79 \%, 11.50 \%, 24.64 \%$ and $25.83 \%)$ for TKN, $(2.66 \%, 6.90 \%, 25.59 \%$ and $26.94 \%)$ for $\mathrm{Na},(5.38 \%, 15.21 \%, 29.74 \%$ and $30.54 \%)$ for $\mathrm{K}$ and $(4.64 \%$, $10.55 \%, 18.05 \%$ and $21.56 \%$ ) for total hardness after 6,12 , 24 and 48 hours of the treatment (Figure 6). Selvarathi and Murugalakshmi (2013) recorded the highest reduction of TDS, EC, BOD, COD, TKN, Na, K, and total hardness (TH) in paper mill effluent treated with different types of phytoadsorbent. Chairgulprasert et al. (2013) reported that the mixture of galangal (Alpinia galanga Willd) leaves and pseudo stems can be used as a phytosorbent for the removal of lead and zinc ions from synthetic wastewater.

Table 1. Changes in physico-chemical characteristics of paper mill effluent using leaf powder of $E$. crassipes as bio-adsorbent.

\begin{tabular}{|c|c|c|c|c|c|c|}
\hline \multirow{2}{*}{ Parameter } & \multirow{2}{*}{$\frac{\text { Before treatment }}{\text { Initial }}$} & \multicolumn{4}{|c|}{ After treatment } & \multirow{2}{*}{$\begin{array}{l}\text { BIS for } \\
\text { irrigation } \\
\text { water }\end{array}$} \\
\hline & & 6 Hours & 12 Hours & 24 Hours & 48 Hours & \\
\hline pH & $5.80 \pm 0.10$ & $6.07 \mathrm{~ns} \pm 0.10$ & $6.24 \mathrm{~ns} \pm 0.14$ & $6.61 \mathrm{~ns} \pm 0.12$ & $6.62 \mathrm{~ns} \pm 0.08$ & $5.5-9.0$ \\
\hline $\operatorname{TDS}\left(\mathrm{mg} \mathrm{L}^{-1}\right)$ & $980.22 \pm 12.52$ & $951.33 * \pm 9.56$ & $888.49 * \pm 8.53$ & $855.96 * * \pm 7.50$ & $848.42 * * \pm 7.67$ & 1900 \\
\hline$E C\left(\mathrm{dS} \mathrm{cm} \mathrm{cm}^{-1}\right)$ & $6.52 \pm 0.11$ & $5.95 \mathrm{~ns} \pm 0.11$ & $4.92 \mathrm{~ns} \pm 0.15$ & $4.11 * \pm 0.18$ & $4.08 * \pm 0.17$ & - \\
\hline BOD $\left(\mathrm{mg} \mathrm{L}^{-1}\right)$ & $86.42 \pm 4.61$ & $84.49 \mathrm{~ns} \pm 5.64$ & $77.93 *_{ \pm}{ }_{4.92}$ & $63.77 *^{*} 4.40$ & $62.56^{*} \pm 3.39$ & 100 \\
\hline $\operatorname{COD}\left(\mathrm{mg} \mathrm{L}^{-1}\right)$ & $281.01 \pm 8.66$ & $274.57 \mathrm{~ns} \pm 9.85$ & $248.54 * \pm 4.29$ & $220.29 * \pm 9.03$ & $218.11 * * \pm 8.59$ & 250 \\
\hline $\mathrm{PO}_{4}{ }^{3-}\left(\mathrm{mg} \mathrm{L}^{-1}\right)$ & $71.46 \pm 6.00$ & $69.51 \mathrm{~ns} \pm 5.02$ & $62.09 * \pm 4.98$ & $51.42 * \pm 4.24$ & $50.13 * \pm 4.33$ & - \\
\hline TKN (mg L $\left.{ }^{-1}\right)$ & $84.99 \pm 3.92$ & $80.92 \mathrm{~ns} \pm 3.09$ & $75.22 * \pm 5.01$ & $64.05 \pm 8.56$ & $63.04 \pm 6.47$ & 100 \\
\hline $\mathrm{Na}\left(\mathrm{mg} \mathrm{L}^{-1}\right)$ & $136.94 \pm 6.66$ & $133.31 \mathrm{~ns} \pm 3.60$ & $127.50 * \pm 4.87$ & $101.91 * * \pm 13.16$ & $100.06^{* * \pm 6.99}$ & - \\
\hline $\mathbf{K}\left(\mathbf{m g ~ L ^ { - 1 } )}\right.$ & $95.01 \pm 3.48$ & $89.90 \mathrm{~ns} \pm 2.34$ & $80.56^{*} \pm 3.56$ & $66.76^{*} \pm 7.29$ & $66.00 * \pm 7.38$ & - \\
\hline Total hardness $\left(\mathrm{mg} \mathrm{L}^{-1}\right)$ & $442.39 \pm 3.78$ & $421.89 \mathrm{~ns} \pm 3.02$ & $395.74 * * \pm 4.54$ & $362.56 * * \pm 9.15$ & $347 * * \pm 9.86$ & 200 \\
\hline
\end{tabular}

Values presented in the table are the mean \pm SE of three replicates; BIS- Bureau of Indian Standards; "“-"Not given in standards; ns- Not significant; *, **. Significantly different at $\mathrm{P}<0.05$ or $\mathrm{P}<0.01$ level of significance of ANOVA.

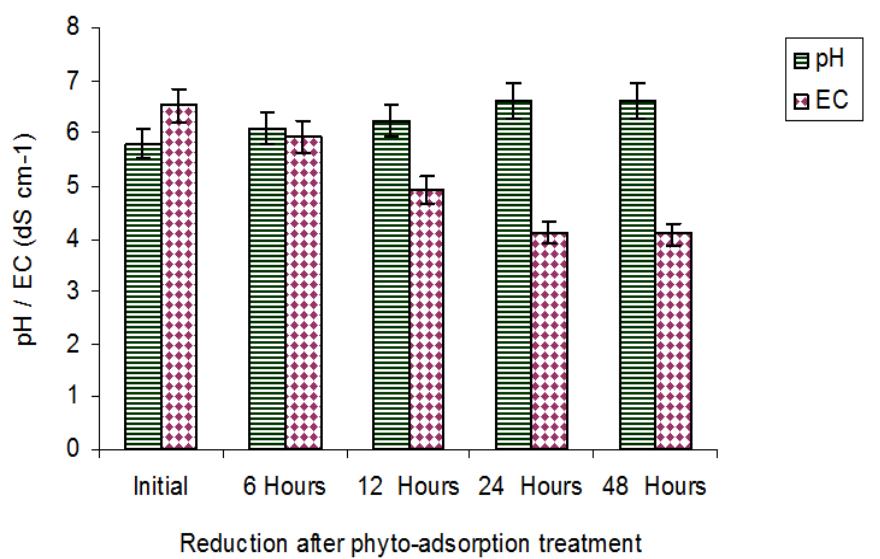

Figures 1. Reduction of $p H$ and EC of paper mill effluent using leaf powder of E. crassipes as phyto-adsorbent.

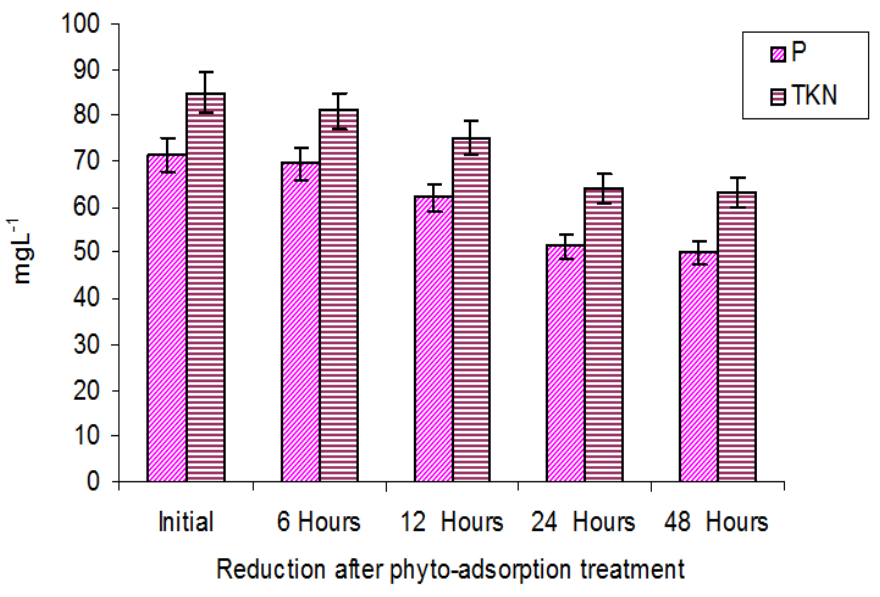

Figures 3. Reduction of $P$ and TKN of paper mill effluent using leaf powder of E. crassipes as phyto-adsorbent.

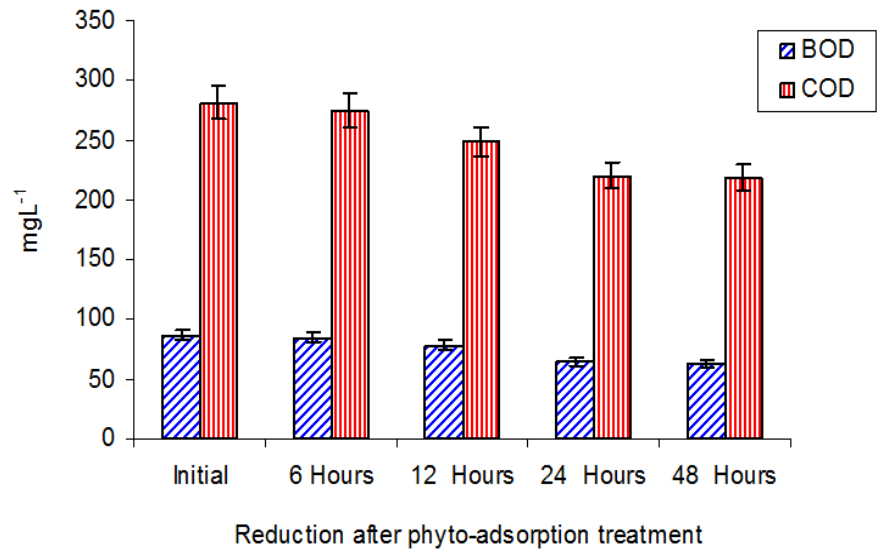

Figures 2. Reduction of BOD and COD of paper mill effluent using leaf powder of E. crassipes as phyto-adsorbent.

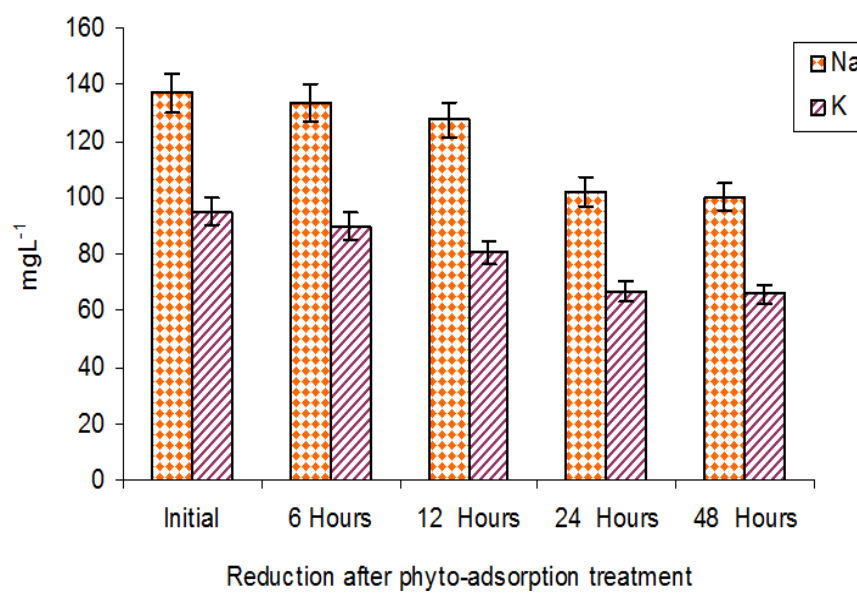

Figures 4. Reduction of $\mathrm{Na}$ and $\mathrm{K}$ of paper mill effluent using leaf powder of E. crassipes as phyto-adsorbent. 


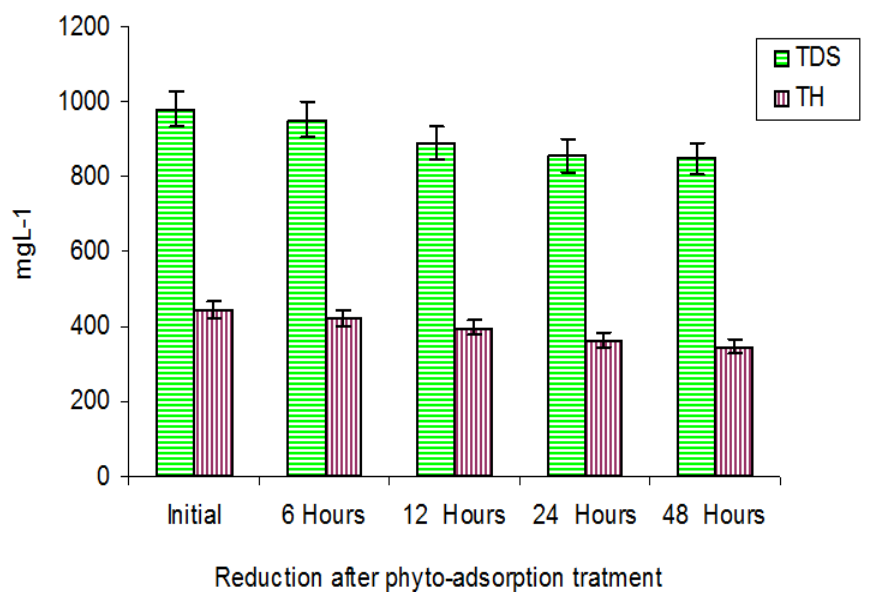

Figures 5. Reduction of TDS and TH of paper mill effluent using leaf powder of E. crassipes as phyto-adsorbent.

\section{Conclusions}

In this present study, a preliminary study was made to find the potential of leaf powder of water hyacinth (E. crassipes) in treating paper mill effluent. application of leaf powder of $E$. crassipes as phyto-adsorbant showed significant $(\mathrm{P}<0.05 /$ $\mathrm{P}<0.01$ ) effect on the removal of TDS, EC, BOD, COD, TKN, $\mathrm{Na}, \mathrm{K}$, and hardness of the paper mill effluent at 12, 24 and 48 hours of phyto-adsorption treatment. It has been found that; phyto-adsorbent considerably decreased the pollution load of paper mill effluent. The result of present study showed that the phyto-adsorbent can be utilized for treating of effluent. It is concluded that the leaf powder of water hyacinth (phytoadsorbent) can be usefully employed to extract nutrients from the paper mill effluent. It is also proved useful in treating effluents polluted with various chemicals components. The study reveals the potential and effectiveness of phytoadsorbent in the removal of nutrients on paper mill effluent. It can also be concluded that the higher density of the phytoadsorbent on paper mill effluent, the more the absorption of nutrients (pollutants) that is, the best of purification will be obtained. Further investigation is required on the removal of pollutants like heavy metals of the paper mill effluent using different vegetative parts of water hyacinth as phytoadsorbent.

Open Access: This is open access article distributed under the terms of the Creative Commons Attribution License, which permits unrestricted use, distribution, and reproduction in any medium, provided the original author(s) and the source are credited.

\section{REFERENCES}

Ahmaruzzaman, M. (2008). Adsorption of phenolic compounds on low-cost adsorbents: a review. Advances in Colloid and Interface Science, 143(1): 48-67.

Annadurai, G., Juang, R. and Lee, D. (2003). Adsorption of heavy metals from water using banana and orange peels. Water Science and Technology, 47(1): 185-190.

APHA (2012). In: Standard Methods for the Examination of Water and Wastewater. American Public Health Association, 21st edition, Washington, DC. pp. 2462.

Chairgulprasert, V., Japakeya, A. and Samaae, H. (2013). Phytoremediation of synthetic wastewater by adsorption of lead and zinc onto Alpinia galanga Willd. Songklanakarin Journal of Science and Technology, 35 (2): 227-233

Chang, K.L., Hsieh, J.F., Ou, B.M., Chang, M.H., Hseih, W.Y., Lin, J.H. and Chen, S.T. (2012). Adsorption studies on the removal of an endocrine-disrupting compound (bisphenol a) using activated carbon from rice straw agricultural waste. Separation

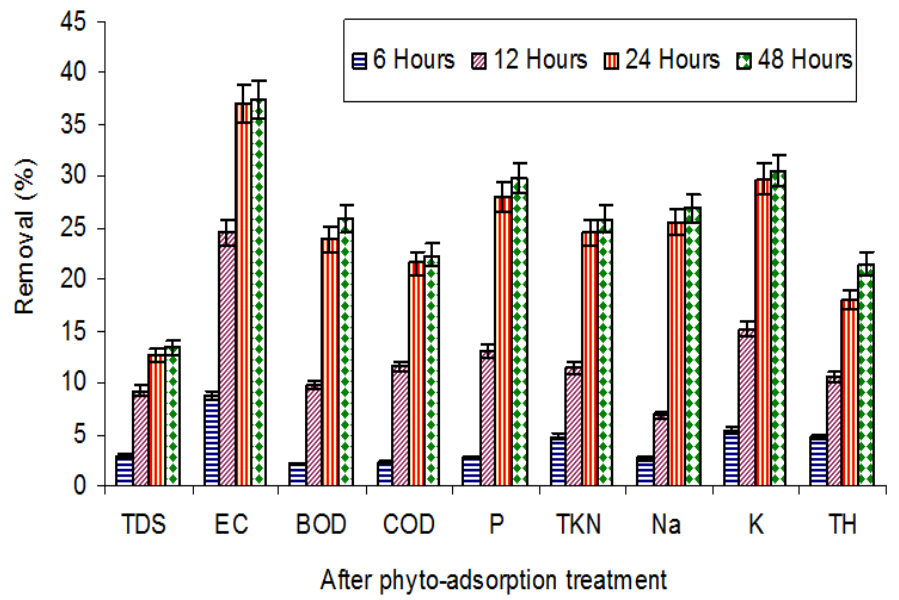

Figure 6. Removal efficiency (\%) of physico-chemical characteristics of paper mill effluent using leaf powder of E. crassipes as phyto-adsorbent at different time.

Science and Technology, 47(10): 1514-1521.

Chaturvedi, R.K. and Sankar, K. (2006). In: Laboratory manual for the physico-chemical analysis of soil, water and plant. Wildlife Institute of India, Dehradun. pp 97.

Deilek, F.B. and Bese, S. (2001). Treatment of pulping effluents using alum and clay-colour removal and sludge characteristics. Water SA, 27(3): 361-366.

Ghaly, M.Y., Jamil, T.S., El-Seey, I.E., Souaya, E.R. and Nasr, R.A. (2011). Treatment of highly polluted paper mill wastewater by solar photocatalytic oxidation with synthesized nano $\mathrm{TiO} 2$. Chem. Eng. J., 168 (1): 446.

Greenpeace. (2011). Hidden Consequences: The costs of industrial water pollution on people, planet and profit. Greenpeace International. The Netherlands.

Jain, M., Garg, V.K. and Kadirvelu, K. (2010). Adsorption of hexavalent chromium from aqueous medium onto carbonaceous adsorbents prepared from waste biomass. Journal of Environmental Management, 91(4): 949-957.

Kumar, V. and Chopra, A.K. (2012). Effect of paper mill effluent irrigation on agronomical characteristics of Vigna radiata (L.) in two different seasons. Communication in Soil Science and Plant Analysis, 43(16):2142-2166. DOI: 10.1080/00103624.2012.697236.

Kumar, V. and Chopra, A.K. (2015). Fertigation with agro-residue based paper mill effluent on a high yield spinach variety. International Journal of Vegetable Science, 21(1): 69-97, DOI: $10.1080 / 19315260.2013 .825690$.

Kumar, V. and Thakur, R. K. (2017). Pollution load of SIDCUL effluent with reference to heavy metals accumulated in sediments using pollution load index (PLI) and geo-accumulation index (i-geo) at Haridwar (Uttarakhand), India. Journal of Environment and Biosciences, 31(1): 163-168.

Kumar, V., Chopra, A.K., Singh, J., Thakur, R.K., Srivastava, S. and Chauhan, R.K. (2016). Comparative assessment of phytoremediation feasibility of water caltrop (Trapa natans L.) and water hyacinth (Eichhornia crassipes Solms.) using pulp and paper mill effluent. Archives of Agriculture and Environmental Science, 1(1): 13-21.

Kumar, V., Chopra, A.K., Srivastava, S., Tomar, V., Thakur, R.K. and Singh, J. (2016). Impact of glass industry effluent disposal on soil characteristics in Haridwar. Journal of Environment and Health Sciences, 2(2): 1- 10.

Kumar, V., Singh, J. and Chopra, A.K. (2017a). Assessment of phytokinetic removal of pollutants of paper mill effluent using water hyacinth (Eichhornia crassipes [Mart.] Solms). Environmental Technology, DOI: 10.1080/09593330.2017.1365944.

Kumar, V., Singh, J. Pathak, V.V., Ahmad, S. and Kothari, R. (2017b). Experimental and kinetics study for phytoremediation of sugar mill effluent using water lettuce (Pistia stratiotes L.) and its end use for biogas production. 3 Biotech, 7: 330, DOI 10.1007/s13205-017-0963-7. 
Kumar, V., Singh, J. and Chopra, A.K. (2017c). Assessment of plant growth attributes, bioaccumulation, enrichment and translocation of heavy metals in water lettuce (Pistia stratiotes L.) grown in sugar mill effluent. International Journal of Phytoremediation, DOI:10.1080/15226514.2017.1393391)

Lazim, Z.M., Hadibarata, T., Puteh, M.H. and Yusop, Z. (2015). Adsorption characteristics of bisphenol a onto low-cost modified phyto-waste material in aqueous solution. Water, Air and Soil Pollution, 226: 34, DOI: 10.1007/s11270-015-2318-5.

Nakanishi, A., Tamai, M., Kawasaki, N., Nakamura, T. and Tanada, S. (2002). Adsorption characteristics of bisphenol a carbonaceous materials produced from wood chips as organic waste. Journal of Colloid and Interface Science, 252(2): 393-396.

Okafor, P., Okon, P., Daniel, E. and Ebenso, E. (2012). Adsorption capacity of coconut (Cocos nucifera L.) shell for lead, copper, cadmium and arsenic from aqueous solutions. International Journal of Electrochemical Science, 7: 12354-12369.

Pagnanelli, F., Mainelli, S., Vegliò, F. and Toro, L. (2003). Heavy metal removal by olive pomace: biosorbent characterisation and equilibrium modelling. Chemical Engineering Science, 58(20): 4709-4717.

Patterson, S.J., Chanasyk, D.S., Mapfumo, E. and Naeth, M.A. (2008). Effects of diluted Kraft pulp mill effluent on hybrid poplar and soil chemical properties. Irrigation Science, 26: 547-560.

Pokhrel, D. and Viraraghavan, T. (2004). Treatment of pulp and paper mill wastewater-a review. Science Total Environment, 333: 37-58.
Rahman, I., Saad, B., Shaidan, S. and Sya Rizal, E. (2005). Adsorption characteristics of malachite green on activated carbon derived from rice husks produced by chemical-thermal process. Bioresource Technology, 96(14): 1578-1583.

Selvarathi, P. and Murugalakshmi, K.R. (2015). Analysis of physico chemical characteristics of bioadsorbent treated paper mill effluent. International Journal of Science and Research, 4(6): 1137-1139.

Shweta, S. and Rai, J.P.N. (2010) Heavy metal adsorption from aqueous solution using Eichhornia crassipes dead biomass. International Journal of Mineral Processing, 94: 203-206.

Tsai, W.T., Lai, C.W. and Su, T.Y. (2006). Adsorption of bisphenola from aqueous solution onto minerals and carbon adsorbents. Journal of Hazardous Materials, 134(1-3): 169-175, doi:10.1016/j.jhazmat.2005.10. 0558.

Wan Ngah, W. and Hanafiah, M. (2008). Removal of heavy metal ions from wastewater by chemically modified plant wastes as adsorbents: a review. Bioresource Technology, 99(10), 39353948.

Wang, F.Y., Wang, H. and Ma, J.W. (2010). Adsorption of cadmium (ii) ions from aqueous solution by a new low-cost adsorbentbamboo charcoal. Journal of Hazardous Materials, 177(1): 300306.

Wirasnita, R., Hadibarata, T., Yusoff, A. and Yusop, Z. (2014). Removal of bisphenol from aqueous solution by activated carbon derived from oil palm empty fruit bunch. Water, Air and Soil Pollution, 225(10): 1-12, doi: 10.1007/s11270-014-2148-x. 